\title{
PENGARUH STRES KERJA TERHADAP TURNOVER INTENTION DENGAN DUKUNGAN SOSIAL SEBAGAI VARIABEL PEMODERASI
}

\author{
I Gede Aditya Pradana Putra ${ }^{1}$ \\ Ida Bagus Ketut Surya ${ }^{2}$
}

\author{
Fakultas Ekonomi dan Bisnis Universitas Udayana (Unud), Bali, Indonesia \\ email: adityapradanaputra96@gmakl.com
}

\begin{abstract}
ABSTRAK
Tujuan penelitian ini untuk mengetahui bukti empiris pengaruh stres kerja terhadap turnover intention dengan dukungan sosial sebagai variabel pemoderasi pada karyawan Obyek penelitian ini adalah Turnover Intention pada De vins sky Hotel Seminyak. Metode pengumpulan data yang digunakan adalah metode kuesioner. Teknik analisis data yang digunakan dalam penelitian ini adalah teknik analisis deskriptif. Uji hipotesis menggunakan analisis regresi linier berganda, Moderated Regression Analysis (MRA). Berdasaarkan hasil analisis menunjukkan bahwa Stres kerja berpengaruh positif dan signifikan terhadap turnover intention di De vins sky Hotel Seminyak Bali. Dukungan Sosial berpengaruh negatif dan signifikan terhadap turnover intention di De vins sky Hotel Seminyak Bali. Dukungan sosial mampu memoderasi (memperlemah) hubungan antara stres kerja dan turnover intention di De vins sky Hotel Seminyak Bali.
\end{abstract}

Kata kunci: stres kerja, dukungan sosial, turnover intention

\begin{abstract}
The purpose of this study is to find empirical evidence of the effect of work stress on turnover intention with social support as a moderating variable on employees The object of this study is Turnover Intention on De vins sky Hotel Seminyak. Data collection method used was a questionnaire method. Data analysis technique used in this research is descriptive analysis technique. Hypothesis testing uses multiple linear regression analysis, Moderated Regression Analysis (MRA). Based on the results of the analysis shows that work stress has a positive and significant effect on turnover intention at De vins sky Hotel Seminyak Bali. Social Support has a negative and significant effect on turnover intention at De vins sky Hotel Seminyak Bali. Social support is able to moderate (weaken) the relationship between work stress and turnover intention at De vins sky Hotel Seminyak Bali.

Keywords: work stress, social support, turnover intention
\end{abstract}




\section{PENDAHULUAN}

Sumber daya manusia (SDM) merupakan faktor penting dalam perusahaan yang menentukan berhasil atau tidaknya suatu perusahaan dalam mencapai tujuan (Ardana et al., 2011) menyatakan bahwa sumber daya manusia adalah harta atau aset yang paling berharga dan paling penting dimiliki oleh suatu organisasi, karena keberhasilan organisasi sangat ditentukan oleh unsur manusia. SDM adalah sosok yang memainkan peran sebagai alat operasional perusahaan terpenting dibandingkan faktor-faktor operasional lainnya. Sumber Daya Manusia merupakan kekuatan daya fikir dan berkarya manusia yang masih tersimpan dalam dirinya yang perlu digali, dibina serta dikembangkan untuk dimanfaatkan sebaik-baiknya bagi kesejahteraan kehidupan manusia (Ardana et al., 2011).

Sumber daya manusia merupakan faktor produksi yang mampu menggerakkan faktor-faktor produksi lainnya. Pengetahuan, keterampilan, kompetensi, karakteristik setiap individu karyawan adalah penentu masa depan perkembangan perusahaan. Oleh karena itu, penekanan perhatian sumber daya manusia disebuah perusahaan harus mendapatkan posisi yang lebih dari faktor lainnya. Pada realisasinya, mengelola SDM untuk menjadikan aset perusahaan yang utama bukanlah hal yang mudah. Banyak permasalahan pengelolaan SDM yang ditemukan pada praktiknya, salah satu permasalahan yang banyak ditemukan disetiap perusahaan adalah Turnover atau tingkat keluar masuknya karyawan di perusahaan tersebut.

Robbins dan Judge (2008:38), menyatakan bahwa turnover intention merupakan saat seorang karyawan memiliki kecendrungan untuk berhenti dari pekerjaannya, sedangkan turnover merupakan pengunduran diri permanen baik secara sukarela maupun tidak sukarela dari suatu organisasi. Turnover intention yang tinggi akan menimbulkan kerugian bagi perusahaan, karena akan mengurangi produktifitas perusahaan ataupun organisasi. Meskipun turnover intention pada umumnya berdampak buruk terhadap organisasi, turnover intention seringkali dibutuhkan oleh perusahaan yang memiliki karyawan dengan kinerja yang rendah (Kardiman \& Dian, 2012). Turnover Intention memiliki dampak yang signifikan bagi perusahaan terkait dengan pengeluaran biaya yang cukup besar karena harus melakukan perekrutan ulang, orientasi, pelatihan, lembur, hingga pengawasan (Kharismawati \& Dewi, 2016). Oleh karena itu, turnover intention perlu diperhatikan karena akan mempengaruhi aktivitas jalannya sebuah perusahaan dan pengeluaran biaya yang tinggi untuk perekrutan ulang, orientasi, pelatihan.

Bertambahnya beban kerja dan faktor-faktor lain dapat menimbulkan stres dan ketidak nyamanan bagi karyawan sehingga mengganggu kinerjanya (Sugiyanto et al., 2016) mengatakan bahwa kelelahan fisik secara terus menerus maka stres kerja akan meningkat pada karyawan. Karyawan yang dimiliki oleh perusahaan adalah makhluk sosial yang memiliki latar belakang, keperibadian dan cara berpikir yang tersendiri. Karyawan juga seringkali mempunyai cara yang berbeda dalam menyikapi masalah termasuk dalam hal penanganan stres sehingga perusahaan tidak dapat memprediksi sikap karyawan tersebut yang dikhawatirkan akan menganggu dalam proses pencapaian tujuan. Seperti yang dikatakan oleh (Arshadi \& Damiri, 2013) dalam penelitiannya menunjukkan bahwa stres kerja memiliki hubungan positif dengan turnover intention. (Syahronica \& Ruhana, 2015) bahwa 
stres merupakan faktor dominan yang mempengaruhi turnover intention, hal tersebut sejalan dengan pendapat (Manurung, 2012) yang menyatakan bahwa stres berpengaruh positif terhadap turnover intention pada karyawan. Oleh karena itu, perusahaan harus melakukan tindakan dan pendekatan untuk memahami kebutuhan karyawannya sehingga dapat mengurangi tingkat turnover intention yang terjadi. Salah satu pendekatan yang dapat diberikan kepada karyawan adalah dukungan sosial.

Putra, (2015) mengatakan bahwa Stres Kerja berpengaruh positif terhadap Turnover Intention. Khaidir \& Sugiati (2016) mengatakan bahwa variabel stres kerja pada karyawan kontrak PT. GSM berpengaruh positif terhadap turnover intention. Hasan (2014), mengatakan bahwa stres kerja berpengaruh positif terhadap turnover intention. Hal ini berarti menggambarkan ketika stres kerja meningkat, maka kondisi turnover intention pun meningkat. Hakim \& Darmawati (2016) Stres kerja berpengaruh positif dan signifikan terhadap turnover intention. Miitchell et al. (2014) yang menyatakan stres kerja berpengaruh positif dan signifikan pada turnover intention. Septiari \& Ardana (2016) yang menyebutkan bahwa stres kerja mempunyai pengaruh positif dan signifikan terhadap turnover intention karyawan pada Hotel Asana Putra Bali.

Dukungan sosial adalah sikap mendorong atau simpati terhadap seseorang dengan beberapa cara tertentu antara lain pemberian nasihat, informasi, dll yang dapat memberikan kenyamanan dan rasa dihargai sebagai seorang induvidu (Ardhina \& Padmantyo, 2017). Lobburi et al. (2012) mengatakan bahwa dukungan sosial faktor lain yang mempengaruhi turnover intention. Lebih lanjut dijelaskan bahwa dukungan sosial yang dirasakan adalah proses interaksi sosial dan komunikasi dalam jaringan sosial yang bergantung pada berbagai jenis hubungan, seperti hubungan sosial, hubungan keluarga, dan hubungan kerja. Oleh karena itu, jika dalam masyarakat seseorang memiliki ikatan sosial yang kuat dengan keluarga dan teman-temannya maka terdapat kecendrungan orang tersebut menunjukkan turnover intention yang rendah.

Lobburi et al. (2012) mengatakan bahwa dukungan sosial (atasan, rekan kerja, kerabat dan teman-teman) berpengaruh negatif terhadap turnover intention. Kharismawati \& Dewi, (2016) yang mengatakan bahwa komitmen organisasional, dukungan sosial dan iklim etika berpengaruh negatif terhadap turnover intention karyawan Guest Services Assistant di PT Indonesia Air Asia Denpasar. Ardhina \& Padmantyo, (2017) Dukungan sosial memoderasi stres kerja terhadap turnover intention memiliki pengaruh negatif signifikan. Berdasarkan latar belakang tersebut, akan dilakukan penelitian pada karyawan De vins sky Hotel Seminyak. Dalam empat tahun terakhir terdapat peningkatan karyawan yang keluar dari perusahaan yang ditunjukkan pada Tabel 1 .

Tabel 1. menunjukkan bahwa terjadi kecendrungan penurunan karyawan yang keluar dari tahun 2015 - 2016 dari 10,95 persen menjadi 5,91 persen dan mengalami peningkatan pada tahun 2017 menjadi 8,69 persen. Namun, pada tahun 2018 turnover karyawan meningkat kembali menjadi 24,86 persen. Menurut Gillis (1994) (dalam Setiawan, 2013) turnover karyawan dikatakan normal berkisar antara 5-10 persen pertahun, dan tergolong tinggi apabila lebih dari 10 persen per tahun. 
Tabel 1.

Jumlah Karyawan De vins sky Hotel Seminyak yang Keluar Dari Perusahaan

\begin{tabular}{lcccccc}
\hline Tahun & $\begin{array}{c}\text { Jumlah } \\
\text { karyawan } \\
\text { awal } \\
\text { tahun } \\
\text { (orang) } \\
(1)\end{array}$ & $\begin{array}{c}\text { Jumlah } \\
\text { karyawan } \\
\text { akhir } \\
\text { tahun } \\
\text { (orang) }\end{array}$ & $\begin{array}{c}\text { Rata-rata } \\
\text { karyawan } \\
(3)=(1)+(2): 2\end{array}$ & $\begin{array}{c}\text { Karyawan } \\
\text { keluar } \\
\text { (orang) } \\
(4)\end{array}$ & $\begin{array}{c}\text { Karyawan } \\
\text { masuk } \\
\text { (orang) }(5)\end{array}$ & $\begin{array}{c}\text { Karyawan } \\
\text { keluar }(\%) \\
(6)=(4):(3) \mathrm{x} \\
100 \%\end{array}$ \\
\hline 2015 & 67 & 79 & 73 & & & \\
2016 & 79 & 90 & 84,5 & 5 & 20 & 10,95 \\
2017 & 90 & 94 & 92 & 8 & 16 & 5,91 \\
2018 & 94 & 91 & 92,5 & 23 & 20 & 8,69 \\
\hline
\end{tabular}

Berdasarkan Tabel 1. turnover karyawan pada tahun 2018 mencapai 24,86 persen. Berdasarkan hasil wawancara dengan management, tingginya tingkat turnover karyawan terjadi karena dari mereka merasa beban disaat kedatangan tamu yang sangat ramai sehingga membuat karyawan dituntut bekerja lebih extra agar dapat memberikan pelayanan yang maksimal terhadap tamu. Yang dimana membuat karyawan merasa pusing sehingga pikiran tidak dapat berkonsentrasi dalam melakukan pekerjaan. Disisi lain ketika hotel sepi pengunjung membuat karyawan merasa stres dikarenakan mereka tidak mendapat service tambahan dari para pengunjung yang menginap dihotel. Service yang diperoleh oleh karyawan juga belum bisa mengimbangi dukungan kerja dari keluarga, karena waktu untuk berlibur dengan keluarga kurang. Kejenuhan yang dirasakan karyawan karena melakukan pekerjaan yang monetun membuat karyawan ingin mencari suasana baru dan memutuskan untuk keluar dari hotel.

Dari latar belakang ini dapat ditarik simpulan bahwa ada masalah turnover karyawan yang cukup serius karena dapat menimbulkan efek buruk bagi management De vins sky Hotel Seminyak. Dengan tingginya tingkat turnover pada tahun 2018 tidak menutup kemungkinan adanya peningkatan turnover intention pada tahun berikutnya pada karyawan De vins sky Hotel Seminyak.

Setiap karyawan memiliki sifat, status, fikiran, keinginan dan kebutuhan yang berbeda. Apabila perusahaan tidak dapat mempertahankan karyawan yang potensial atau yang biasa saja, ini akan berakibat buruk terhadap perusahaan. Jika karyawan sudah merasa bosan dan tidak nyaman maka ia akan tidak bergairah untuk menjalankan pekerjaannya dan berfikir untuk mencari pekerjaan lain yang dianggap lebih baik. Keluarnya karyawan dari suatu perusahaan untuk mencari pekerjaan lain merupakan gejala turnover intention. Dari definisi tersebut dapat dikemukakan turnover intention adalah merupakan suatu keinginan berpindah karyawan dari satu tempat kerja ke tempat kerja lainnya, belum sampai pada tahap realisasi yaitu melakukan perpindahan dari satu tempat kerja ke tempat kerja lainnya. Angka perputaran yang tinggi akan mengakibatkan bengkaknya biaya perekrutan, seleksi, dan pelatihan. Selain itu tingkat perputaran karyawan yang terlalu besar atau melibatkan karyawan berharga akan menjadi faktor pengganggu yang menghalangi efektifitas organisasi 
Menurut Robbins (2018:430) terdapat faktor-faktor yang dapat mempengaruhi stres kerja antara lain faktor lingkungan, faktor organisasi, dan faktor individu. Dalam kehidupan sehari-hari manusia tidak terlepas dari adanya faktor lingkungan salah satunya adalah lingkungan sosial, dimana manusia membutuhkan orang lain untuk memenuhi kebutuhannya, maka dari itu diperlukan adanya suatu dukungan sosial.

Menurut Lobburi et al. (2012), dukungan sosial dan dukungan organisasi dapat mempengaruhi kepuasan kerja dan hasil pekerjaan yang berhubungan dengan komitmen organisasional dan keinginan berpindah karyawan. Hal ini dikarenakan tujuan dukungan sosial bagi individu untuk saling membantu pada bidang sosial, untuk mengurangi ketidakpastian, kecemasan, dan stres ketika individu dihadapkan dengan masalah dan krisis.

Dukungan organisasi yang dirasakan karyawan akan menyampaikan makna peduli dan perhatian untuk kesejahteraan karyawan. Dukungan sosial yang dirasakan oleh karyawan merupakan proses interaksi sosial dan komunikasi dalam jaringan sosial yang bergantung pada berbagai jenis hubungan, seperti hubungan sosial, hubungan keluarga, dan hubungan kerja. Oleh karena itu, dalam masyarakat dengan ikatan sosial yang kuat dengan keluarga dan teman-teman, seperti dalam budaya kolektivis, faktor non-kerja (misalnya, keluarga dan teman-teman, kekerabatan, dll) juga dapat mempengaruhi kepuasan kerja dan hasil kerja yang berkaitan dengan karyawan seperti komitmen organisasional dan turnover intention Stres merupakan isu utama yang menjadi perhatian, karena telah menjadi bagian dari kehidupan karyawan, dan sulit untuk menghindari stres dalam pekerjaan (Parvaiz et al., 2015). Robbins (2008:368), mengatakan bahwa stres sebagai suatu ketidakseimbangan antara keinginan dan kemampuan memenuhinya sehingga menimbulkan konsekuensi penting bagi dirinya. Hasibuan (2009:204), mengatakan bahwa stres kerja adalah suatu kondisi yang mempengaruhi emosi, proses berfikir dan kondisi seseorang, sehingga menyebabkan nervous dan merasakan kekuatiran kronis. Jadi stres kerja dapat di nyatakan sebagai suatu tekanan yang dirasakan karyawan dalam pekerjaannya, yang bersumber dari tugas, pimpinan dan lingkungan kerja, sehingga mempengaruhi emosi, proses berpikir dan kondisi karyawan tersebut.

Hasan, (2014), mengatakan bahwa stres kerja berpengaruh positif terhadap turnover intention. Hal ini berarti menggambarkan ketika stres kerja meningkat, maka kondisi turnover intention pun meningkat. Miitchell et al. (2014) yang mengatakan stres kerja berpengaruh positif dan signifikan pada turnover intention. Putra (2015) mengatakan bahwa stres kerja berpengaruh positif terhadap turnover intention. Siddiqui \& Jamil (2015)menunjukkan bahwa terdapat hubungan positif dan langsung antara stres kerja dan turnover intention, sehingga peningkatan stres kerja akan meningkatkan pula keinginan berpindah kerja. Khaidir \& Sugiati, (2016) mengatakan bahwa variabel stres kerja pada karyawan kontrak PT. GSM berpengaruh positif terhadap turnover intention. Septiari \& Ardana (2016) yang mengatakan bahwa stres kerja mempunyai pengaruh positif dan signifikan terhadap turnover intention karyawan pada Hotel Asana Putra Bali. Berdasarkan uraian di atas, maka dapat disimpulkan bahwa stres kerja memiliki pengaruh yang positif 
terhadap turnover intention. Berdasarkan pemahaman tersebut dapat dirumuskan hipotesis pertama sebagai berikut.

$\mathrm{H}_{1}$ : Stres kerja berpengaruh positif dan signifikan terhadap turnover intention karyawan pada De vins sky Hotel Seminyak Bali.

Dukungan sosial merupakan dukungan yang diterima seseorang baik secara langsung maupun tidak langsung yang dapat membuatnya merasa dihargai dan memberikan efek positif bagi individu yang menerimanya. Dukungan sosial yang dirasakan oleh karyawan merupakan proses interaksi sosial dan komunikasi dalam jaringan sosial yang bergantung pada berbagai jenis hubungan, seperti hubungan sosial, hubungan keluarga, dan hubungan kerja. Oleh karena itu, dalam masyarakat dengan ikatan sosial yang kuat dengan keluarga dan teman-teman, seperti dalam budaya kolektivis, faktor non-kerja (misalnya, keluarga dan teman-teman, kekerabatan, dll) juga dapat mempengaruhi kepuasan kerja dan hasil kerja yang berkaitan dengan karyawan turnover intention.

Persepsi dukungan organisasi mempunyai korelasi negatif yang signifikan terhadap intensi pindah kerja kayawan. Jika dukungan organisasi rendah terhadap karyawan maka intensi pindah kerja menjadi tinggi ataupun sebaliknya (Suryaningrum, 2015). Acker \& Gila (2004) juga menyatakan bahwa konflik dalam keluarga dapat menyebabkan meningkatnya keinginan berpindah karyawan. Berarti, dukungan sosial berpengaruh negatif terhadap keinginan berpindah karyawan. Lobburi et al., (2012) yang juga mengemukakan bahwa dukungan sosial (atasan, rekan kerja, kerabat dan teman-teman) berpengaruh negatif terhadap turnover intention. Kharismawati \& Dewi (2016) yang mengatakan bahwa komitmen organisasional, dukungan sosial dan iklim etika berpengaruh negatif terhadap turnover intention karyawan Guest Services Assistant di PT Indonesia Air Asia Denpasar. Berdasarkan uraian di atas, maka dapat disimpulkan bahwa dukungan sosial berpengaruh negatif dan signifikan terhadap turnover intention. Berdasarkan pemahaman tersebut dapat dirumuskan hipotesis kedua sebagai berikut.

$\mathrm{H}_{2}$ : Dukungan Sosial berpengaruh negatif dan signifikan terhadap Turnover Intention karyawan pada De vins sky Hotel Seminyak Bali.

Dukungan Sosial adalah informasi atau umpan balik dari orang lain yang menunjukkan bahwa seseorang dicintai dan diperhatikan, dihargai, dan dihormati, dan dilibatkan dalam jaringan komunikasi dan kewajiban yang timbal balik (King, 2012). Seseorang yang mempunyai dukungan sosial rendah sangat rentan terkena stres karena ketidaknyamanan lingkungan kerja yang disebabkan oleh kurang harmonisnya hubungan antar karyawan. Dalam sebuah organisasi atau lingkungan kerja tidak saja dukungan itu dari sesama karyawan dukungan dari atasan dan juga dari keluarga sangat penting untuk kenyamanan seorang karyawan.

Fadhilah (2010) Menyimpulkan keinginan untuk keluar karyawan akan menurun jika karyawan yang bersangkutan mendapat dukungan dari rekan kerja dan keluarga, dukungan rekan kerja dan keluarga mutlak menurunkan turnover intention yang disebabkan oleh stres kerja. Ranu (2014) menyatakan seseorang yang memiliki dukungan sosial yang baik maka dia dapat meredam stres yang terjadi dalam pekerjaan mereka maka dapat disimpulkan bahwa dukungan sosial dapat menekan stres sehingga tingkat turnover dapat dikendalikan. Wibowo \& 
Intan (2004) yang membuktikan bahwa dukungan sosial dari tempat kerja dan keluarga memoderasi hubungan antara tekanan keluarga dengan keinginan berpindah. Chui, Cheong dan Fong (2018) menyimpulkan bahwa dukungan sosial secara signifikan memoderasi stres kerja terhadap turnover intention, dalam penelitiannya yang berjudul efek moderasi dari dukungan sosial pada stres kerja dan intensi keluar karyawan. Ardhina \& Padmantyo, (2017) Dukungan sosial memoderasi stres kerja terhadap turnover intention memiliki pengaruh negatif signifikan. Berdasarkan uraian di atas, maka dapat disimpulkan bahwa dukungan sosial memperlemah stres kerja terhadap turnover intention. Berdasarkan pemahaman tersebut dapat dirumuskan hipotesis ketiga sebagai berikut.

$\mathrm{H}_{3}$ : Dukungan Sosial memperlemah Stres Kerja terhadap Turnover Intention pada

De vins sky Hotel Seminyak Bali.

Turnover intention adalah niat meninggalkan perusahaan secara sukarela, yang dapat mempengaruhi status perusahaan dan dengan pasti akan mempengaruhi produktivitas karyawan (Issa \& Mohammad, 2013). Turnover Intention adalah derajat kecenderungan sikap yang dimiliki oleh karyawan untuk mencari pekerjaan baru di tempat lain atau adanya rencana untuk meninggalkan perusahaan dalam masa tiga bulan yang akan datang, enam bulan yang akan datang, satu tahun yang akan datang, dan dua tahun yang akan (Dharma, 2013). Menurut Handoko (2001) permintaan berhenti dapat terjadi jika seorang karyawan melihat kesempatan karir yang lebih besar di tempat lain. Turnover dapat diartikan sebagai aliran para karyawan yang masuk dan keluar perusahaan (Ronodiputro \& Husnan, 1995).

Setiap karyawan memiliki sifat, status, fikiran, keinginan dan kebutuhan yang berbeda. Apabila perusahaan tidak dapat mempertahankan karyawan yang potensial atau yang biasa saja, ini akan berakibat buruk terhadap perusahaan. Jika karyawan sudah merasa bosan dan tidak nyaman maka ia akan tidak bergairah untuk menjalankan pekerjaannya dan berfikir untuk mencari pekerjaan lain yang dianggap lebih baik. Keluarnya karyawan dari suatu perusahaan untuk mencari pekerjaan lain merupakan gejala turnover intention.

Dari definisi tersebut dapat dikemukakan turnover intention adalah merupakan suatu keinginan berpindah karyawan dari satu tempat kerja ke tempat kerja lainnya, belum sampai pada tahap realisasi yaitu melakukan perpindahan dari satu tempat kerja ke tempat kerja lainnya. Angka perputaran yang tinggi akan mengakibatkan bengkaknya biaya perekrutan, seleksi, dan pelatihan. Selain itu tingkat perputaran karyawan yang terlalu besar atau melibatkan karyawan berharga akan menjadi faktor pengganggu yang menghalangi efektifitas organisasi.

Faktor-faktor yang menjadi penyebab turnover intention pegawai adalah stres kerja dan dukungan sosial Ardhina \& Padmantyo (2017). Oleh karena itu menurut Maertz dan Campion 1998 (dalam Samad 2006) proses identifikasi terhadap faktorfaktor yang mempengaruhi niat untuk pindah (turnover intention) menjadi suatu hal yang penting untuk dipertimbangkan dan menjadi sesuatu yang efektif untuk menurunkan angka turnover yang sebenarnya.

Indikasi terjadinya turnover intentions menurut Harnoto (2002) adalah 1) Absensi yang meningkat. Pegawai yang berkinginan untuk melakukan pindah kerja, biasanya ditandai dengan absensi yang semakin meningkat. Tingkat tanggung 
jawab pegawai dalam fase ini sangat kurang dibandingkan dengan sebelumnya. 2) Mulai malas bekerja. Pegawai yang berkinginan untuk melakukan pindah kerja, akan lebih malas bekerja karena orientasi pegawai ini adalah bekerja di tempat lainnya yang dipandang lebih mampu memenuhi semua keinginan pegawai bersangkutan. 3) Peningkatan terhadap pelanggaran tata tertib kerja. Berbagai pelanggaran terhadap tata tertib dalam lingkungan pekerjaan sering dilakukan pegawai yang akan melakukan turnover. Pegawai lebih sering meninggalkan tempat kerja ketika jam-jam kerja berlangsung, maupun berbagai bentuk pelanggaran lainnya. 4) Peningkatan protes terhadap atasan. Pegawai yang berkeinginan untuk melakukan pindah kerja, lebih sering melakukan protes terhadap kebijakan-kebijakan perusahaan kepada atasan. Materi protes yang ditekankan biasanya berhubungan dengan balas jasa atau aturan lain yang tidak sependapat dengan keinginan pegawai.

Menurut Robbins (2018:429) stres kerja adalah suatu kondisi dinamis individu yang dihadapkan pada sebuah peluang, tuntutan, atau sumber daya yang terkait dengan apa yang diinginkan oleh individu dan yang mana hasilnya dipandang menjadi tidak pasti dan penting. Sedangkan menurut Moorhead \& Griffin (2013:175) stres kerja merupakan suatu respon adaptif seseorang terhadap rangsangan yang menempatkan tuntutan fisik atau psikologis secara berlebihan kepadanya. Menurut Wijono (2010:122) stres kerja adalah suatu kondisi dari hasil penghayatan subjektif individu yang dapat berupa interaksi antara individu dan lingkungan kerja yang dapat mengancam dan memberikan tekanan psikologis, fisiologis, dan sikap individu. Hakim \& Darmawati, (2016) menjelaskan bahwa stres kerja sebenarnya tidak selalu buruk, karena stres memiliki nilai positif ketika menjadi peluang saat menawarkan potensi hasil.

Menurut Robbins (2018:430) terdapat faktor-faktor yang dapat mempengaruhi stres kerja antara lain faktor lingkungan, faktor organisasi, dan faktor individu. Dalam kehidupan sehari-hari manusia tidak terlepas dari adanya faktor lingkungan salah satunya adalah lingkungan sosial, dimana manusia membutuhkan orang lain untuk memenuhi kebutuhannya, maka dari itu diperlukan adanya suatu dukungan sosial.

Dukungan Sosial adalah informasi atau umpan balik dari orang lain yang menunjukkan bahwa seseorang dicintai dan diperhatikan, dihargai, dan dihormati, dan dilibatkan dalam jaringan komunikasi dan kewajiban yang timbal (King, 2012). Menurut (Lobburi et al., 2012) dijelaskan bahwa dukungan sosial yang dirasakan adalah proses interaksi sosial dan komunikasi dalam jaringan sosial yang bergantung pada berbagai jenis hubungan, seperti hubungan sosial, hubungan keluarga, dan hubungan kerja. Oleh karena itu, jika dalam masyarakat seseorang memiliki ikatan sosial yang kuat dengan keluarga dan teman-temannya maka terdapat kecendrungan orang tersebut menunjukkan turnover intention yang rendah. Dukungan sosial merupakan dukungan yang diterima seseorang baik secara langsung maupun tidak langsung yang dapat membuatnya merasa dihargai dan memberikan efek positif bagi individu yang menerimanya.

Menurut (Lobburi et al., 2012), dukungan sosial dan dukungan organisasi dapat mempengaruhi kepuasan kerja dan hasil pekerjaan yang berhubungan dengan komitmen organisasional dan keinginan berpindah karyawan. Hal ini dikarenakan 
tujuan dukungan sosial bagi individu untuk saling membantu pada bidang sosial, untuk mengurangi ketidakpastian, kecemasan, dan stres ketika individu dihadapkan dengan masalah dan krisis.

Dukungan organisasi yang dirasakan karyawan akan menyampaikan makna peduli dan perhatian untuk kesejahteraan karyawan. Dukungan sosial yang dirasakan oleh karyawan merupakan proses interaksi sosial dan komunikasi dalam jaringan sosial yang bergantung pada berbagai jenis hubungan, seperti hubungan sosial, hubungan keluarga, dan hubungan kerja. Oleh karena itu, dalam masyarakat dengan ikatan sosial yang kuat dengan keluarga dan teman-teman, seperti dalam budaya kolektivis, faktor non-kerja (misalnya, keluarga dan teman-teman, kekerabatan, dll) juga dapat mempengaruhi kepuasan kerja dan hasil kerja yang berkaitan dengan karyawan seperti komitmen organisasional dan turnover intention.

Sumber dukungan sosial banyak diperoleh indivindu dari lingkungan sekitarnya. Sumber dukungan sosial merupakan aspek paling penting untuk diketahui dan dipahami. Dengan pengetahuan dan pemahaman tersebut, seseorang akan tahu kepada siapa ia akan mendapatkan dukungan sosial sesuai dengan situasi dan keinginannya yang spesifik, sehingga dukungan sosial memiliki makna yang berarti bagi kedua belah pihak.

Sumber-sumber dukungan sosial menurut Goldberger \& Breznitz (dalam Apollo \& Cahyadi, 2012: 261) adalah orang tua, saudara kandung, anak-anak, kerabat, pasangan hidup, sahabat rekan sekerja, dan juga tetangga. Hal yang sama juga diungkapkan oleh Wentzel dalam (Apollo \& Cahyadi, 2012) bahwa sumbersumber dukungan sosial adalah orang-orang yang memiliki hubungan yang berarti bagi individu. Dukungan sosial dapat berasal dari pasangan atau patner, anggota keluarga, kawan, kontak sosial masyarakat, dan teman kerja atau atasan anda di tempat kerja (Taylor, dkk., 2009:555). Dukungan sosial dapat diaplikasikan ke dalam lingkungan keluarga, yaitu orang tua. Jadi dukungan sosial orang tua adalah dukungan yang diberikan oleh orang tua kepada anaknya baik secara emosional, penghargaan, informasi.

Hubungan sosial dapat membantu hubungan psikologis, memperkuat praktik hidup sehat, dan membantu pemulihan dari sakit hanya ketika hubungan itu bersifat sportif. Dukungan sosial mungkin paling efektif apabila ia "tidak terlihat". Dukungan sosial juga membantu memperkuat fungsi kekebalan tubuh, mengurangi respons fisiologis terhadap stres, dan memperkuat fungsi untuk merespons penyakit kronis. Ketika kita mengetahui bahwa ada orang lain yang akan membantu kita, kita merasa ada beban emosional, yang mengurangi efektivitas dukungan sosial yang kita terima. Tetapi ketika dukungan sosial itu diberikan secara diam-diam, secara otomatis, berkat hubungan baik kita, maka ia dapat mereduksi stres dan meningkatkan kesehatan. (Taylor dkk., 2009: 555-556).

Berdasarkan permasalahan yang telah dikemukakan, kajian teoritis, dan tinjauan penelitian terdahulu dapat digambarkan kerangka konseptual sebagai berikut. 


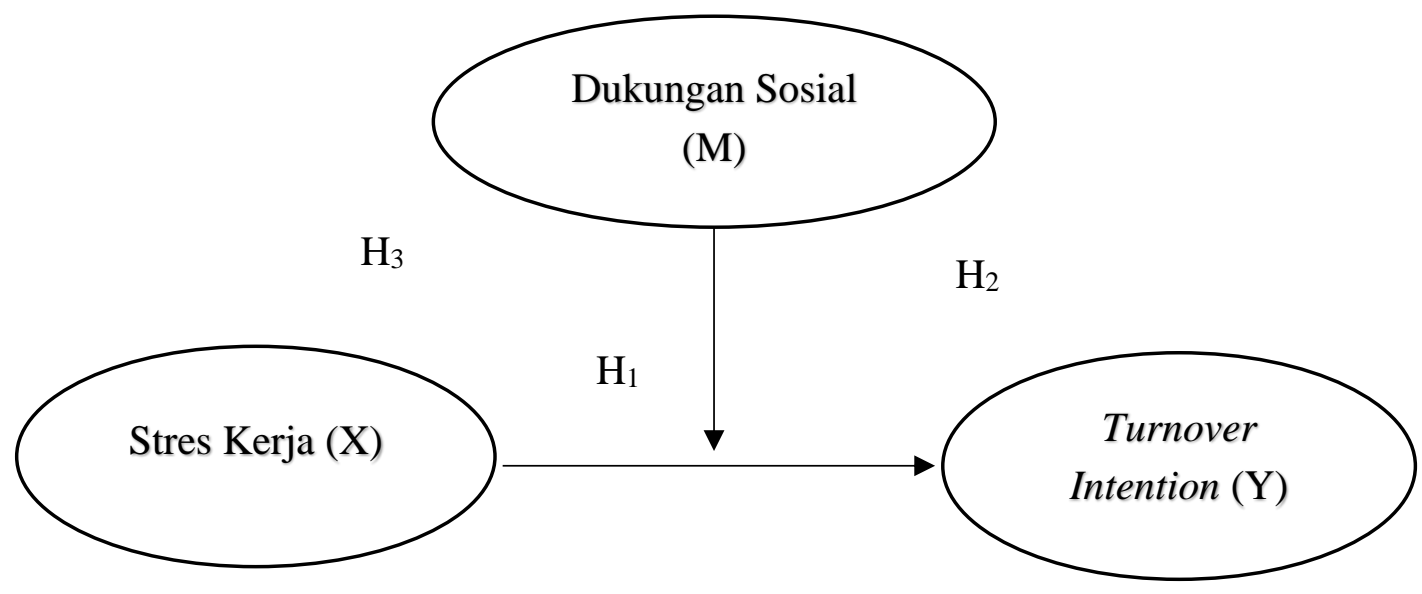

Gambar 1 .Kerangka Konseptual

\section{METODE PENELITIAN}

Penelitian ini dilakukan di De vins sky Hotel Seminyak yang beralamat di, Jl. Petitenget No. 35, Seminyak, Kuta, Badung, Bali. Adapun alasan yang melatarbelakangi peneliti melakukan penelitian di De vins sky Hotel Seminyak yang merupakan usaha yang bergerak dibidang jasa akomodasi pariwisata, harus mampu memberikan jaminan atas kualitas layanan kepada wisatawan dengan dukungan dari karyawannya. Tingginya tingkat turnover karyawan terjadi karena dari mereka merasa beban disaat kedatangan tamu yang sangat ramai sehingga membuat karyawan dituntut bekerja lebih extra agar dapat memberikan pelayanan yang maksimal terhadap tamu. Yang dimana membuat karyawan merasa pusing sehingga pikiran tidak dapat berkonsentrasi dalam melakukan pekerjaan. Disisi lain ketika hotel sepi pengunjung membuat karyawan merasa stres dikarenakan mereka tidak mendapat service tambahan dari para pengunjung yang menginap dihotel. Service yang diperoleh oleh karyawan juga belum bisa mengimbangi dukungan kerja dari keluarga, karena waktu untuk berlibur dengan keluarga kurang. Kejenuhan yang dirasakan karyawan karena melakukan pekerjaan yang monetun membuat karyawan ingin mencari suasana baru dan memutuskan untuk keluar dari hotel.

Populasi dalam penelitian ini adalah seluruh karyawan De vins sky Hotel Seminyak yang berjumlah 97 orang. Teknik penentuan sampel yang digunakan dalam penelitian ini adalah metode sampling jenuh. Sampling jenuh adalah teknik penentuan sampel bila semua anggota populasi digunakan sebagai sampel.

Teknik analisis data yang digunakan dalam penelitian ini adalah teknik analisis deskriptif. Uji hipotesis menggunakan teknik analisis regresi linier berganda, Moderated Regression Analysis (MRA). Sebelum melakukan analisis regresi linier berganda model dalam penelitian harus lolos uji asumsi klasik. Apabila model dalam penelitian sudah dinyatakan valid dan sudah memenuhi 
asumsi-asumsi dasar dalam analisis regresi maka, uji dapat dilanjutkan dengan menggunakan uji analisis regresi linier berganda.

\section{HASIL DAN PEMBAHASAN}

Sebuah instrument dikatakan valid apabila dapat digunakan untuk mengukur apa yang seharusnya diukur. Dengan melakukan uji validitas instrument, maka hasil penelitian diharapkan akan menjadi valid. Pengujian validitas tiap butir pertanyaan atau pernyataan dalam instrument penelitian ini digunakan analisis item yaitu mengkorelasikan skor tiap item dengan skor total item.

Tabel 2.

\section{Hasil Uji Validitas}

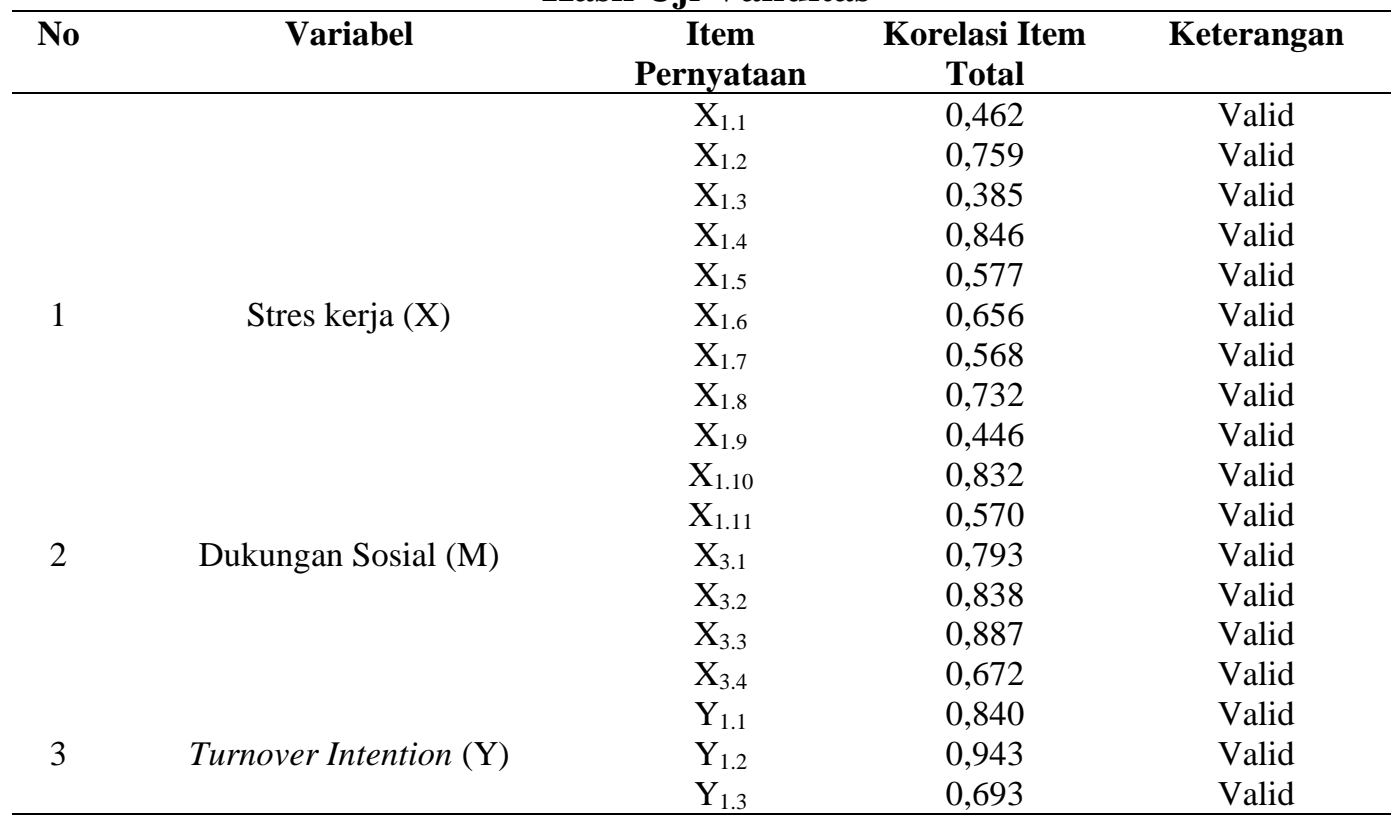

Sumber: Data diolah, 2019

Berdasarkan hasil uji validitas pada Tabel 2. di atas menunjukkan bahwa seluruh pernyataan pada variabel stres kerja, dukungan sosial dan turnover intention memiliki nilai koefisien product moment correlation pearson dengan skor total seluruh item pernyataan lebih besar dari 0,30, sehingga seluruh indikator tersebut telah memenuhi syarat validitas data dan dapat dinyatakan valid.

Sebuah instrument yang reliabel adalah instrument yang digunakan beberapa kali dan tetap ada kesamaan data dalam waktu yang berbeda. Dengan melakukan uji reliabilitas instrument, suatu alat pengukur dipakai dua kali untuk mengukur gejala yang sama dan hasil pengukuran yang diperoleh relatif konsisten. Pengujian reliabilitas tiap butir pertanyaan atau pernyataan dalam instrument penelitian ini menggunakan metode koefisien Cronbach's Alpha. Instrument dikatakan reliabel 
untuk mengukur variabel bila berada di atas angka 0,60. Hasil pengujian reliabilitas instrument dapat dilihat pada Tabel 3.

Berdasarkan Tabel 3. ditunjukkan bahwa ketiga instrument penelitian yaitu variabel stres kerja, dukungan sosial dan turnover intention memiliki koefisien Cronbach's Alpha lebih besar dari 0,60 sehingga seluruh pernyataan tersebut memenuhi syarat reliabilitas instrument dan dapat dinyatakan reliabel.

Model analisis regresi moderasi digunakan untuk mendapat koefisien regresi yang akan menentukan apakah hipotesis yang dibuat akan diterima atau ditolak. Adapun hasil analisis regresi dengan program Statitical Pacage of Social Science (SPSS) versi 21.0 for Windows dapat dilihat pada Tabel 4. berikut.

Tabel 3.

Hasil Uji Reliabilitas

\begin{tabular}{clcc}
\hline No & \multicolumn{1}{c}{ Variabel } & Cronbach's Alpha & Keterangan \\
\hline $\mathbf{1}$ & Stres kerja $(\mathrm{X})$ & 0,822 & Reliabel \\
$\mathbf{2}$ & Dukungan sosial $(\mathrm{M})$ & 0,808 & Reliabel \\
$\mathbf{3}$ & Turnover intenton $(\mathrm{Y})$ & 0,759 & Reliabel \\
\hline
\end{tabular}

Sumber: Data diolah, 2019

Tabel 4.

Rangkuman Hasil Analisis Regresi Moderasi

\begin{tabular}{|c|c|c|c|c|c|}
\hline \multirow{2}{*}{\multicolumn{2}{|c|}{ Variabel }} & \multicolumn{2}{|c|}{ Koefisien Regresi } & \multirow{2}{*}{$\mathbf{T}$} & \multirow{2}{*}{ Sig } \\
\hline & & B & Std. error & & \\
\hline Stres kerja & & 0,448 & 0,083 & 5,406 & 0,000 \\
\hline Dukungan Sosial & & $-0,202$ & 0,083 & $-2,437$ & 0,017 \\
\hline Moderasi (X.M) & & $-0,423$ & 0,085 & $-4,978$ & 0,000 \\
\hline (Constant) & $: \quad 0,013$ & & & & \\
\hline F Statistik & : 19,033 & & & & \\
\hline Sig F & $: \quad 0,000$ & & & & \\
\hline $\mathrm{R}^{2}$ & $: 0,38$ & & & & \\
\hline
\end{tabular}

Sumber: Data diolah, 2019 berikut:

Berdasarkan Tabel 4. dapat ditulis persamaan regresi moderasi sebagai

$$
\mathrm{Y}=0,013+0,448 \mathrm{X}-0,202 \mathrm{M}-0,423 \mathrm{X} \cdot \mathrm{M}
$$

Dimana

$$
\begin{array}{ll}
\mathrm{Y} & =\text { Turnover Intention } \\
\mathrm{X} & =\text { Stres Kerja } \\
\mathrm{M} & =\text { Dukungan Sosial }
\end{array}
$$

Persamaan regresi moderasi tersebut menunjukkan arah masing-masing variabel bebas terhadap variabel terikatnya. Persamaan regresi linear berganda tersebut dapat diuraikan sebagai berikut :

$\mathrm{X} \quad=0,448$, menunjukkan bahwa stres kerja berpengaruh positif signifikan terhadap turnover intention De vins sky Hotel Seminyak Bali dengan kata 
lain apabila stres kerja karyawan tinggi maka turnover intention juga akan mengalami peningkatan.

M = -0,202, menunjukkan bahwa dukungan sosial berpengaruh negatif signifikan terhadap turnover intention De vins sky Hotel Seminyak Bali dengan kata lain apabila dukungan sosial karyawan tinggi maka turnover intention akan mengalami penurunan.

X.M = Nilai koefisien regresi moderasi (X.M) adalah -0,423 dengan tingkat signifikansi sebesar 0,000, artinya apabila interaksi variabel stres kerja dan dukungan sosial meningkat maka turnover intention cenderung mengalami penurunan. Artinya tingkat stres yang tinggi apabila mendapatkan dukungan sosial yang baik dapat mempengaruhi rendahnya turnover intention

$\mathrm{R}^{2} \quad=0,380$ yang berarti bahwa sebesar 38 persen turnover intention di De vins sky Hotel Seminyak Bali dipengar uhi oleh stres kerja dan interaksi antara stres kerja dan dukungan sosial, sedangkan sisanya sebesar 62 persen dipengaruhi oleh variabel lainnya di luar model penelitian.

Model regresi dikatakan model yang baik apabila dalam model tersebut bebas dari asumsi klasik statistik. Suatu model regresi linear berganda secara teoritis akan menghasilkan nilai parameter penduga yang tepat bila memenuhi persyaratan asumsi klasik regresi, yaitu: uji normalitas, multikolinearitas, dan heteroskedastisitas.

Uji Normalitas merupakan suatu uji statistik yang digunakan untuk menguji apakah dalam model regresi, variabel pengganggu atau residual memiliki distribusi normal atau tidak. Model regresi yang baik yaitu memiliki distribusi residual yang normal atau mendekati normal. Uji normalitas dapat dilakukan secara kuantitatif dengan menggunakan Kolmogrov-Smirnov. Data dapat dikatakan berdistribusi normal apabila Asimp.sig (2-tailed) >level of significant $(\alpha=0,05)$ dan tidak berdistribusi normal apabila nilai Asimp.sig (2-tailed) <level of significant $(\alpha=$ $0,05)$.

Tabel 5.

Hasil Uji Normalitas

\begin{tabular}{lr}
\hline & $\begin{array}{c}\text { Unstandardized } \\
\text { Residual }\end{array}$ \\
\hline N & 97 \\
Test Statistic & .080 \\
Asymp. Sig. (2-tailed) & .142 \\
\hline Sumber: Data diolah, 2019 &
\end{tabular}

Berdasarkan Tabel 5. dapat diketahui bahwa nilai Asymp. Sig. (2-tailed) sebesar 0,142 dan lebih besar dari $\alpha=0,05$. Jadi, dapat disimpulkan bahwa data tersebut telah memenuhi syarat normalitas dan data tersebut dikatakan berdistribusi normal.

Uji multikolinearitas digunakan untuk menguji apakah model regresi ditemukan adanya korelasi antar variabel bebas. Model regresi yang baik 
seharusnya tidak terjadi korelasi diantara variabel bebasnya atau bebas dari gejala multikolinear. Tolerance mengukur variabilitas variabel bebas yang terpilih yang tidak dapat dijelaskan oleh variabel bebas lainnya. Berdasarkan aturan variance inflation factor (VIF) dan tolerance, apabila VIF melebihi angka 10 atau tolerance kurang dari 0,10 maka dinyatakan terjadi gejala multikolinearitas. Sebaliknya apabila nilai VIF kurang dari 10 atau tolerance lebih dari 0,10 maka dinyatakan tidak terjadi gejala multikolinearitas.

Tabel 6.

Hasil Uji Multikolinearitas

\begin{tabular}{|c|c|c|}
\hline \multirow[b]{2}{*}{ Variabel } & \multicolumn{2}{|c|}{ Collinearity Statistics } \\
\hline & Tolerance & VIF \\
\hline Stres kerja & 0,972 & 1,029 \\
\hline Dukungan Sosial & 0,966 & 1,036 \\
\hline Var. Moderasi & 0,940 & 1,064 \\
\hline
\end{tabular}

Sumber: Data diolah, 2019

Hasil pengujian tolerance menunjukan seluruh variabel bebas memiliki nilai tolerance lebih besar dari 0,10 (10\%). Hasil perhitungan VIF juga menunjukan bahwa seluruh variabel bebas memiliki nilai VIF kurang dari 10. Oleh karena itu, maka dapat disimpulkan bahwa tidak terjadi multikolinearitas antar variabel independen dalam model regresi tersebut.

Uji heteroskedasitas digunakan untuk menguji apakah dalam model regresi terjadi ketidaksamaan varian dari residual satu pengamatan ke pengamatan yang lain. Jika varian dari residual satu pengamatan ke pengamatan yang lain tetap, maka disebut dengan homoskedastisitas dan jika berbeda disebut dengan heteroskedastisitas. Metode glejser dilakukan dengan meregresikan variabel bebas terhadap absolut residual. Jika tingkat signifikansi masing-masing variabel bebas lebih besar dari 0,05 maka dapat disimpulkan bahwa tidak terdapat heterokedastisitas. Hasil uji heteroskedastisitas ditunjukkan dalam Tabel 7. berikut ini.

Tabel 7.

Hasil Uji Heteroskedastisitas (Metode Glejser)

\begin{tabular}{lcc}
\hline \multicolumn{1}{c}{ Variabel } & T & Signifikansi \\
\hline Stres kerja & $-0,421$ & 0,675 \\
Dukungan sosial & 1,490 & 0,140 \\
Var. Moderasi & 1,944 & 0,055 \\
\hline Sumber: Data diolah, 2019 & &
\end{tabular}

Sumber: Data diolah, 2019

Hasil pengujian menunjukkan bahwa signifikansinya lebih dari $\alpha=0,05$ terhadap absolut residual (abs_Res) secara parsial. Berdasarkan hal tersebut, maka dapat disimpulkan bahwa dalam model regresi tersebut tidak terdapat heteroskedastisitas. 
Hasil Uji Anova atau ( $F$ test) menunjukkan nilai F hitung sebesar 19,033, dengan signifikansi 0,000 yang probabilitas signifikansi lebih kecil dari alpha 0,05. Ini menunjukkan bahwa stres kerja dan interaksi antara stres kerja dan dukungan sosial dapat digunakan untuk memprediksi turnover intention di De vins sky Hotel Seminyak Bali atau dapat dikatakan bahwa stres kerja dan interaksi antara stres kerja dengan dukungan sosial secara bersama-sama berpengaruh terhadap turnover intention di De vins sky Hotel Seminyak Bali. Sehingga model yang digunakan pada penelitian ini adalah layak untuk uji t statistik yang menguji variabel independen secara parsial terhadap variabel dependen.

Uji parsial (uji t) digunakan untuk menguji pengaruh masing-masing variabel bebas stres kerja terhadap turnover intention.Tabel 8. menunjukkan hasil perhitungan uji t dengan menggunakan SPSS.

Tabel 8.

Hasil Uji t

\begin{tabular}{|c|c|c|c|}
\hline Variabel & $\begin{array}{c}\text { Unstandardized Coefficients } \\
\text { Beta }\end{array}$ & t hitung & Sig. \\
\hline Stres kerja $(\mathrm{X})$ & 0,448 & 5,406 & 0,000 \\
\hline Dukungan sosial (M) & $-0,202$ & $-2,436$ & 0,017 \\
\hline Moderasi (X.M) & $-0,423$ & $-4,978$ & 0,000 \\
\hline
\end{tabular}

Sumber: Data diolah, 2019

Berdasarkan hasil analisis diperoleh nilai t sig $=0,000<0,05$ maka $\mathrm{H}_{0}$ ditolak artinya ada pengaruh variabel stres kerja terhadap turnover intention di De vins sky Hotel Seminyak Bali. Berdasarkan hasil penelitian diketahui bahwa nilai signifikansi uji t sebesar 0,000 nilai signifikansi uji t sebesar $0,000<0,05$ maka $\mathrm{H}_{0}$ ditolak, ini berarti bahwa variabel stres kerja berpengaruh terhadap turnover intention di De vins sky Hotel Seminyak Bali. Koefisien regresi X sebesar 0,448, menunjukkan bahwa meningkatnya stres kerja maka akan meningkatkan turnover intention di De vins sky Hotel Seminyak Bali.

Berdasarkan hasil analisis diperoleh nilai t sig $=0,017<0,05$ maka $\mathrm{H}_{0}$ ditolak artinya ada pengaruh variabel dukungan sosial terhadap turnover intention di De vins sky Hotel Seminyak Bali. Berdasarkan hasil penelitian diketahui bahwa nilai signifikansi uji t sebesar 0,017 nilai signifikansi uji t sebesar $0,017<0,05$ maka $\mathrm{H}_{0}$ ditolak, ini berarti bahwa variabel dukungan sosial berpengaruh terhadap turnover intention di De vins sky Hotel Seminyak Bali. Koefisien regresi M sebesar -0,202, menunjukkan bahwa meningkatnya dukungan sosial maka akan mengurangi turnover intention di De vins sky Hotel Seminyak Bali.

Berdasarkan hasil analisis diperoleh nilai tsig $=0,000<0,05$ dengan koefisien beta sebesar $-0,423$, dengan nilai signifikansi sebesar 0,000 yang nilainnya lebih kecil dari tingkat signifkan yang ditetapkan $(\alpha=0,05)$. Dengan demikian dukungan sosial terbukti sebagai variabel moderasi.

Pengujian hipotesis pada pengaruh stres kerja terhadap Turnover Intention di De vins sky Hotel Seminyak Bali menemukan ada pengaruh dari variabel stres kerja terhadap turnover intention dengan hasil (Sig. t $0,000<0,05$ ) serta koefisien beta 
sebesar 0,448 yang menunjukkan bahwa stres kerja berpengaruh positif signifikan terhadap turnover intention di De vins sky Hotel Seminyak Bali, sehingga hipotesis pertama dalam penelitian ini diterima.

Hasil Penelitian ini mendukung hasil penelitian terdahulu yang dilakukan oleh Hasan (2014), mengatakan bahwa stres kerja berpengaruh positif terhadap turnover intention. Miitchell et al. (2014) yang mengatakan stres kerja berpengaruh positif dan signifikan pada turnover intention. Putra (2015) mengatakan bahwa stres kerja berpengaruh positif terhadap Turnover Intention. Siddiqui \& Jamil (2015) menunjukkan bahwa terdapat hubungan positif dan langsung antara stres kerja dan turnover intention. Khaidir \& Sugiati, (2016) mengatakan bahwa variabel stres kerja pada karyawan kontrak PT. GSM berpengaruh positif terhadap turnover intention. Septiari \& Ardana (2016) yang mengatakan bahwa stres kerja mempunyai pengaruh positif dan signifikan terhadap turnover intention karyawan pada Hotel Asana Putra Bali.

Pengujian hipotesis pada pengaruh dukungan sosial terhadap Turnover Intention di De vins sky Hotel Seminyak Bali menemukan ada pengaruh dari variabel dukungan sosial terhadap turnover intention dengan hasil (Sig. t 0,017 < $0,05)$ serta koefisien beta sebesar -0,202 yang menunjukkan bahwa dukungan sosial berpengaruh negatif signifikan terhadap turnover intention di De vins sky Hotel Seminyak Bali, sehingga hipotesis kedua dalam penelitian ini diterima.

Hasil Penelitian ini mendukung hasil penelitian terdahulu yang dilakukan oleh Suryaningrum (2015) Persepsi dukungan organisasi mempunyai korelasi negatif yang signifikan terhadap intensi pindah kerja kayawan. Lobburi et al., (2012) yang juga mengemukakan bahwadukungan sosial (atasan, rekan kerja, kerabatdan teman-teman) berpengaruh negatif terhadap turnover intention. Thanacoody et al. (2009) dan Acker \& Gila (2004) juga menyatakan bahwa konflik dalam keluarga dapat menyebabkan meningkatnya keinginan berpindah karyawan. Berarti, dukungan sosial berpengaruh negatif terhadap keinginan berpindah karyawan. Kharismawati \& Dewi (2016) yang mengatakan bahwa komitmen organisasional, dukungan sosial dan iklim etika berpengaruh negatif terhadap turnover intention karyawan Guest Services Assistant di PT Indonesia Air Asia Denpasar.

Pembahasan pengujian hipotesis berikutnya yaitu dukungan sosial berpengaruh pada hubungan antara stres kerja dan turnover intention. Berdasarkan hasil analisis moderasi, setelah hipotesis di uji, hasilnya menunjukkan bahwa pengaruh stres kerja terhadap turnover intention menurun setelah diinteraksi dengan dukungan sosial. Statemen ini didukung dengan hasil analisis yang menggambarkan bahwa koefisien beta sebesar -0,423, dengan nilai signifikansi sebesar 0,000 yang nilainnya lebih kecil dari tingkat signifkan yang ditetapkan ( $\alpha$ $=0,05)$. Dengan demikian dukungan sosial terbukti sebagai variabel moderasi. Secara umum hal ini menggambarkan bahwa stres kerja yang tinggi dengan nada dukungan sosial yang semakin baik mampu menekan turnver intention. Hasil analisis ini mendukung hipotesis ketiga yakni dukungan sosial berpengaruh pada hubungan antara stres kerja dan turnover intention dengan koefisien beta sebesar 0,423 (memperlemah) dan merupakan pure moderator atau moderasi murni. 
Karyawan yang memperoleh dukungan sosial (meliputi dukungan dari keluarga, rekan kerja maupun atasan/supervisor) yang tinggi maka karyawan tersebut tidak mudah mengalami stres. Hal ini disebabkan karena karyawan tersebut mampu mereduksi beban/tekanan yang diterimanya sehingga karyawan yang memiliki dukungan sosial tinggi maka akan mengelola stres kerja yang dihadapi dengan baik dan memandang stres kerja dengan cara yang berbeda sehingga dapat memberikan dampak yang positif terhadap karyawan. Hasil Penelitian ini mendukung hasil penelitian terdahulu yang dilakukan oleh. Chui, Cheong dan fong (2018) menyimpulkan bahwa dukungan sosial secara signifikan memoderasi stres kerja terhadap turnover intention, dalam penelitiannya yang berjudul efek moderasi dari dukungan sosial pada stres kerja dan intensi keluar karyawam. Fadhilah (2010) Menyimpulkan keinginan untuk keluar karyawan akan menurun jika karyawan yang bersangkutan mendapat dukungan dari rekan kerja dan keluarga, dukungan rekan kerja dan keluarga mutlak menurunkan turnover intention yang disebabkan oleh stres kerja.

Ranu (2014) menyatakan seseorang yang memiliki dukungan sosial yang baik maka dia dapat meredam stres yang terjadi dalam pekerjaan mereka maka dapat disimpulkan bahwa dukungan sosial dapat menekan stres sehingga tingkat turnover dapat dikendalikan. Wibowo \& Intan (2004) yang membuktikan bahwa dukungan sosial dari tempat kerja dan keluarga memoderasi hubungan antara tekanan keluarga dengan keinginan berpindah. Dukungan sosial memoderasi stres kerja terhadap turnover intention memiliki pengaruh negatif signifikan (Ardhina \& Padmantyo, 2017).

\section{SIMPULAN}

Stres kerja berpengaruh positif dan signifikan terhadap turnover intention di De vins sky Hotel Seminyak Bali. Hal tersebut berarti meningkatnya stres kerja, maka akan semakin tinggi turnover intention. Dukungan Sosial berpengaruh negatif dan signifikan terhadap turnover intention di De vins sky Hotel Seminyak Bali. Hal tersebut berarti meningkatnya dukungan sosial, maka akan memperlemah atau mengurangi turnover intention. Peran dukungan sosial sebagai memoderasi adalah (memperlemah) pengaruh hubungan antara stres kerja dan turnover intention di De vins sky Hotel Seminyak Bali. Mengatasi stres kerja yang terjadi di De vins sky hotel dengan membagi tugas yang merata kepada setiap karyawan di masingmasing devisi agar beban kerja yang merata di peroleh oleh setiap karyawan dan karyawan bisa berkonsentrasi dan tidak pusing dalam menyelesaikan pekerjaan. Mengatasi dukungan sosial yang terjadi di De vins sky hotel dengan mengatur shift kerja yang baik agar jam kerja karyawan tidak ada yang jumping, agar karyawan memiliki waktu yang cukup untuk keluarga.

Mengatasi stres kerja yang terjadi di De vins sky Hotel Seminyak Bali dengan membagi tugas yang merata kepada setiap karyawan di masing-masing devisi agar beban kerja yang merata di peroleh oleh setiap karyawan sehingga karyawan bisa berkonsentrasi dan tidak pusing dalam menyelesaikan pekerjaan. Mengatasi dukungan sosial yang terjadi di De vins sky Hotel Seminyak Bali dengan mengatur shift kerja yang baik agar jam kerja karyawan tidak ada yang jumping, sehingga karyawan memiliki waktu yang cukup untuk keluarga. 


\section{REFERENSI}

Acker, D. S. W., \& Gila, M. (2004). The Effect of Organizational Conditions (Role Conflict, RoleAmbiguity, Opportunities for Professional Development, and Social Support) on Job Satisfaction and Intention to Leave Among Social Workers in Mental Health Care. Community Mental Health Journal, 40(1), $65-73$.

Apollo, \& Cahyadi, A. (2012). Konflik Peran Ganda Perempuan Menikah yang Bekerja Ditinjau dari Dukungan Sosial Keluarga dan Penyesuaian Diri. Widya Warta No. 02 Tahun XXXV I, 261-262.

Ardana, K., Mujiati, N, W., \& Mudiartha, U, I, W. (2011). Manajemen Sumber Daya Manusia.

Ardhina, S., \& Padmantyo, S. (2017). Job Stress and Intention Turnover: Does Social Support Matte. The 3rd International Conference on Science, Technology, and Humanity, 2477-3328.

Arshadi, N., \& Damiri, H. (2013). The Relationship of Job Stress with Turnover Intention and Job Performance: Moderating Role of OBSE. Procedia - Social and Behavioral Sciences, 84, 706-710. https://doi.org/10.1016/j.sbspro.2013.06.631

Dharma, C. (2013). "Hubungan Antara Turnover Intention Dengan Komitmen Organisasional di PT.X Medan." Jurnal Ekonomi Dan Bisnis Jurusan Administrasi Niaga Politeknik Negeri Medan, 1(2), 1-9.

Hakim, M. L., \& Darmawati, A. (2016). Pengaruh Stres Kerja dan Kesempatan Promosi Terhadap Turnover Intention. Jurnal Manajemen, 10.

Handoko, H. (2001). Manajemen Personalia \& Sumber Daya Manusia.

Hasan, R. (2014). Factor Influencing Turnover Intention Among Technical Employees in Information Technology Organization: A Case of XYZ (M) SDN. BHD. International Journal of Arts and Commerce, 3(9).

Issa, D. A. R., \& Mohammad, F. A. (2013). Job Satisfaction and Turnover Intention Based on Sales Person Standpoint. Middle-East Journal of Scientific Esearch, 14(4), 525-531.

Kardiman., I., \& Dian, R. (2012). Pengaruh Budaya Organisasi, Komitmen Organisasi, dan Kepuasan Kerja terhadap Turnover Intention Karyawan (Studi Kasus Pada PT Nyonya Mener Semarang). Juraksi, 1(1), 57-72.

Khaidir, M., \& Sugiati, T. (2016). Pengaruh Stres Kerja, Kompensasi Dan Kepuasan Kerja Terhadap Turnover Intention Studi Pada Karyawan Kontrak Pt. Gagah Satria Manunggal Banjarmasin. Jurnal Wawasan Manajemen, 4(3), 175-185. 
Kharismawati, D. A. P., \& Dewi, I. G. A. M. (2016). Pengaruh Komitmen Organisasional, Dukungan Sosial, dan Iklim Etika terhadap Turnover Intention. E-Jurnal Manajemen Unud., 5(2), 1368.

King, L. A. (2012). Psikologi Umum : Sebuah Pandangan Apresiatif Buku 2.

Lobburi, P. P. D., Kokkrabrue., M., \& Samutsakorn. (2012). The Influence Of Organizational And Social Support On Turnover intention In Collectivist Contexts. The Journal of Applied Business Research, 28(1), 93-104.

Manurung, M. T. (2012). Analisis Pengaruh Stres Kerja dan Kepuasan Kerja Terhadap Turnover Intention Karyawan (Studi Pada STIKES Widya Husada Semarang). Diponegoro Journal of Accounting, 1(2), 145-157.

Putra, R. P. (2015). Pengaruh Stres Kerja Dan Kepuasan Gaji Terhadap Turnover Intention Dengan Gender Sebagai Variabel Moderating (Studi Pada Kantor Akuntan Publik Di Yogyakarta Dan Surakarta). Jurnal Nominal, Iv(3), 8395.

Ranu, E. (2014). Stres kerja, motivasi kerja, dengan dukungan sosial sebagai variabel moderator. Jurnal Ilmu Manajemen, 2(2), 600-612.

Ronodiputro, \& Husnan, S. (1995). Manajemen Sumber Daya Manusia.

Septiari, N. K., \& Ardana, I. K. (2016). Pengaruh Job Insencurity dan Stres Kerja terhadap Turnover Intention Karyawan pada Hotel Asana Agung Putra Bali. E-Jurnal Manajemen Unud., 5(10), 6429.

Siddiqui, A. A., \& Jamil, R. A. (2015). Antecedents of Employees\&rsquo; Turnover Intentions: Evidence from Private Educational Institutions. American Journal of Economics and Business Administration, 7(4), 160-165. https://doi.org/10.3844/ajebasp.2015.160.165

Sugiyanto, E., Irawati, Z., \& Padmanyo, S. (2016). Konflik Pekerja Keluarga dan Pengaruhnya Terhadap Kininerja Pegawai (Studi Kasus Rumah Sakit Berbasis Islam di Surakarta). Iqtishadia, 9(1), 27.

Suryaningrum, T. (2015). Pengaruh Beban Kerja dan Dukungan Sosial terhadap Stres Kerja pada Perawat RS PKU Muhammadiyah Yogyakarta.

Syahronica, G., \& Ruhana, M. S. H. I. (2015). Pengaruh Kepuasan Kerja dan Stres Kerja terhadap Turnover Intention (Studi Pada Karyawan Departemen Dunia Fantasi PT Pembangunan Jaya Ancol, Tbk). Jurnal Administrasi Bisnis, 20(1), 1 .

Thanacoody, P. R., Timothy, B., \& Gian, C. (2009). The Effects of Burnout and Supervisory Social Support on the Relationship Between Work-Family Conflict and Intention to Leave A Study of Australian Cancer Workers. 
E-Jurnal Manajemen, Vol. 9, No. 7, $2020:$ 2790-2809

Journal of Health Organization and Management, 23(1), 53-69.

Wibowo, H., \& Intan, N. Q. A. (2004). Dukungan Sosial sebagai Variabel Pemoderasi Hubungan Antara Tekanan Keluarga dengan Kepuasan Kerja dan Kepuasan Keluarga (Studi pada Karyawan Perbankan di Surakarta). Fokus Manajerial, 2(1), 1-16. 